\title{
Analysis of Learning Mathematics in Kindergarten
}

\author{
Reni Dwi Susanti \\ Study Program of Mathematics Education \\ University of Muhammadiyah Malang, Indonesia \\ renidwi@umm.ac.id
}

\begin{abstract}
Abstarct - This study focused on the analysis of Mathematics learning at the grade B Students Kindergarten. The main purposes are: (a) to describe the suitability of Mathematics lesson plan that has designed by the teacher based on the government standard, (b) to describe the appropriate implementation of Mathematics learning by the lesson plan based on the government standard, and (c ) to describe the evaluation of Mathematics learning based on the government standard. The three points above orientate to the government standard, that is the National Education's Ministry's regulation (Permendiknas) No 58/2009. The results of this study showed that the indicator of Mathematics learning (7\%) was from all indicators at the development scope of the grade B students. The suitability of Mathematics lesson plan based on the government standard $(94,11 \%)$. The suitability between the plan and the implementation of Mathematics learning (95\%). The appropriate implementation of Mathematics learning based on the government standard $(95,45 \%)$. The appropriate evaluation of Mathematics learning based on the government standard $(85,71 \%)$. In addition, it concluded that the qualified Mathematics learning at Kindergarten very appropriated for the standard that was determined by the government.
\end{abstract}

Key words - analysis, the study of Mathematics Learning Kindergarten

\section{INTRODUCTION}

The classification of early childhood educational institutions are regulated in the regulation of the Ministries of national education of the Republic Indonesia No. 58/2009 about early childhood Education Standards [1], expressed that education for early childhood held before Elementary school level, through the formal education, non-formal, and informal. On the path to formal education shaped kindergarten, Raudatul Athfal (RA), and other forms are equal; on the non-formal as a Group play (KOBER), Garden Nursery (TPA), and other forms are equal; While on the informal education and family education shaped by the environment.

Kindergarten is a time or level of education is the lowest level that is commonly referred to as preschool education which is said to be the place of the school for early childhood. Early childhood is a child on the stage of the age of $0-8$ years, this period is often called the golden age [2]. The goal of learning in kindergartens is increasing the creativity of children to learn to get to know a wide variety of science one is for mathematical subjects. Mathematics is a knowledge that is able to develop the ability to think children [3] [4]. An assessment of the concept of the child's thinking is done through several approaches. Through this approach the value in accordance with the standards of the early childhood education that is formulated by the Government, including development aspects, namely: (a) the moral and religious values, (b) socialemotional, (c) cognitive (intellectual), (d) language, (e) motoric physical and (f) the Arts [1]. Standard contents are then relied upon in the development of learning plans and syllabus used by education providers in particular kindergarten.

Through the approach expected learning objectives in kindergarten can be achieved. To achieve that goal can be done in various ways, one of them by applying the appropriate learning. According to the statutes of the national education system Number 20/2003 [5], learning is a process of interactions with educators and learners learning resources in an environment. Learning has three key components, namely the planning, implementation and evaluation. The third component is a sequential system that has to be done in order.

Learning math at kindergarten level, very well developed considering at this time the gold was his for the growing swell of all knowledge. However, it should be noted that the learning math to early childhood is certainly different to adults either about methods or the content [6]. In terms of learning should be introduced through the media that supports, but in fact many schools that do not use the media directly, they still use abstract media [7]. Early mathematics knowledge listed in the sphere of child development in the cognitive aspects have been formulated in Permendiknas No. 58 year 2009. Thus, the analysis of the learning of mathematics in kindergarten can be examined in order to see the process from the process of planning, implementation and evaluation with a look at early childhood education standards specifically for preschool

Following the third learning process that will be in this research analysis: (a) describe the planning of learning mathematics that have been designed by teachers who then visits for compliance with government standards, (b) describe the suitability of learning math with implementation planning has been made and the suitability of its implementation by government standards, and (c) describe the evaluation of the learning of mathematics as well as for compliance with government standards.

\section{METHODS}

This type of research is qualitative descriptive. The method of conducted in the research starting from the planning phase that includes the study of literature, the study of airy and discovery issues. Next is the implementation phase begins with 
defining the problem, devise a research instrument, taking data and the final stage is analyzing the data.

In accordance with the research objectives namely to describe mathematical learning in kindergarten. Data sources include the following: (a) the person, (b) paper, (c) place , a data type that is used is the primary data and secondary data. On the qualitative research with a descriptive approach in General to obtain data done several ways, namely (a) engineering documentation, (b) the techniques of observation, and (c) interview techniques. Analysis of these data-oriented purpose of this study, namely: (a) describe the planning of learning mathematics in kindergarten at pre-school B, (b) describe the implementation of learning mathematics in kindergarten at level, (c) describes the evaluation of the learning of mathematics in kindergarten at pre-school B.

\section{RESULT}

The results of the research and data analysis is based on data obtained at the time of research with the aim to find out the learning of mathematics in kindergarten. Data obtained in the form of a description of the process of learning the mathematical aspects cognitive development seen in the field of basic mathematical ability at pre-school B includes: (a) analysis of the planning stages of learning that is described the planning of learning mathematics that have been designed by teachers who then visits for compliance with government standards, (b) analysis of the implementation stage i.e. describing the suitability of learning math with implementation planning that have been made and the suitability of its implementation by government standards, and (c) the analysis of the evaluation stage i.e. describe mathematical learning evaluation as well as for compliance with government standards.

\section{A. The Planning Of Learning Mathematics}

Based on data obtained through the initial documentation i.e. data about the planning of learning which includes planning the semester, Weekly Activity Units and Daily Activities Unit . In this case it will be described the planning of learning mathematics at pre-school B and compliance regarding the planning of learning mathematics that was created with government standards.

In General according to Permendiknas No. 58 year 2009 on process standards kindergarten, planning of learning include several standards that serve as a reference. These standards include the following: (a) development planning, (b) planning and (c) organizing planning. The standard has the third sub referable standards/guidelines in the planning process of learning. Details can be seen on copies Permendiknas No. 58 year 2009.

Semester planning adjusted with the theme and sub-theme are developed each week based on time allocation. The scope of the development on the subject of mathematics embodied in the sphere of development of cognitive achievement levels comprising the development, product development, and the indicators that will be achieved. The following figure 5 explains the basic concept of percentage matematikapada the scope of the development of Group B.

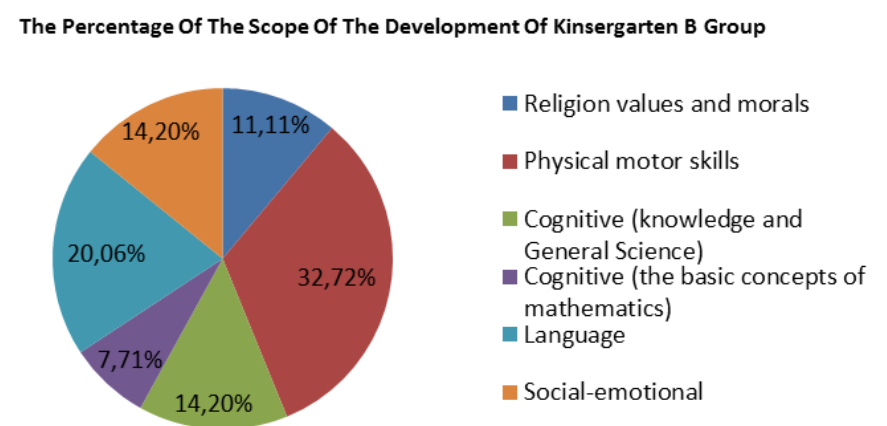

Fig.1 The Percentage Of The Scope Of The Development Of Kinsergarten B Group

Analysis on suitability of planning learning mathematics that have been made include the following aspects: (a) development planning, (b) planning and (c) organizing planning. With these three aspects guided that each aspect there are indicators that become guidelines, results of the analysis of the data shows the suitability of planning the learning that has been made in whole of $94.11 \%$ with score achieved is 16 . Thus it can be concluded that learning planning included in suit.

\section{B. The Implementation of Learning Mathematics}

Implementation of learning mathematics is the implementation of learning that has been added or planned by the teacher, in this case is the implementation of Daily Activities Unit. Based on data obtained from observation, aiming at describing the implementation of learning mathematics in kindergarten. In General, the activity of learning in kindergarten include: (a) the initial activities, (b) the core activities, (c) break/eat, and (d) activities cover (Permendiknas No.: 58, 2009). The learning activities are standard provided by the Government that the policy can be tailored to each institution kindergarten with a note not far from the rules set.

Based on the results of data analysis regarding the suitability of learning mathematics implementation shows that the planning of learning that is made is included in the category of very appropriate with implementation were observed. Acquisition of the average score obtained on a daily basis during the process of with the observation that the percentage of $95 \%$. Analysis on suitability of learning mathematics implementation with the standard implementation that includes 10 principles of learning kindergarten of $95.45 \%$ level for compliance, with the average score achieved every day is 21 . Thus it can be concluded that learning implementation included in the category.

\section{The Evaluation of Learning Mathematics}

The evaluation of the learning outcomes have the stages of planning, implementation and reporting. The following stages of evaluation of learning outcomes that are done: 


\section{1) Planning The Evaluation Of Learning Outcomes}

In the planning stages, a teacher planning assessment tool that is used for each of the learning activities. This planning includes part of planning the learning embodied in the Daily activities of the Unit. Standard assessment techniques on Permendiknas No. 58/2009 consist of: (a) use techniques of observation, (b) the assignment of performance, (c) the recording of anecdotes (d) conversation/dialogue, (e) reports of elderly people, (f) portfolio, and ( $\mathrm{g}$ ) a description of the profile. Assessment techniques used are (a) performance, (b) frequently asked questions, (c) the practice of direct observation, (d) and (e) project/assignment

\section{2) Implementation of The Evaluation of Learning Outcomes}

Implementation of the evaluation of learning outcomes do when learning activities do. The process is performed throughout the children doing activities that have been planned. The form of its execution is on each learning activity conducted, adjusted to assessment techniques are used. Based on the data obtained, and then summarized in Daily Activities Unit which contained the assessment column consisting of a column of assessment tools and developments. In a column written assessment tools the tools used to assess child development on each activity in accordance with the valuation techniques used. Development of the column is a column that is used to write down a summary of the results of the child's development by category of assessment in the form of an asterisk (*) instead of in the form of numbers. Description of symbols the values as follows:
a) $* /$ asterisk $1=$ undeveloped
b) $* *$ / asterisk $2=$ started to develop
c) $* * * /$ asterisk $3=$ develop appropriate expectations
d) $* * * * /$ asterisk $4=$ developing good

\section{3) Reporting The Evaluation Of Learning Outcomes}

Report the results of learning kindergarten students group B concluded in a review of the development of the student daily. report of the results of the study to all aspects of the development and is the result of child development in a day. Aspects that are judged are as follows: (a) religious and moral values, (b) social emotional, (c) language, (d) the cognitive, and (e) physical motor. Reports on the results of the study have been obtained indicators were assessed on mathematical topics are: understanding the amount of numbers and the number of tepukkan objects with the hands as well as understand the geometric shapes, number 1-20, classify geometric shapes with beams, sort geometric shapes.

The assessment is only done on indicators into the planning. On the development of conditioning only as taught in students without assessment done in writing. The indicators assessed has been planned on the daily activities of the Unit. Report student learning outcomes in the form of an assessment of the development of the student daily collected to provide monthly reports of students. This monthly report was then made reference to reporting semester. Reporting form different semester with daily reports, that is no longer the star-shaped symbol description to has been reached each child. Format writing in the form of a descriptive narrative that describes the developments achieved students based on five aspects of development. These aspects include the following: (a) religious and moral values, (b) social emotional, (c) language, (d) the cognitive, and (e) physical motor. Reporting results this semester which is then called with the semester report communicated to the parents in writing. On the results of the analysis of the suitability of learning evaluation made by teacher of $85.71 \%$ with score achieved was 12 . Thus it can be concluded that learning evaluation are included in the category of very fit.

\section{CONCLUSION}

Learning is a process that makes the person doing a learning activity. Learning is a system that has the consistency of the process with a sequence of planning, implementation and evaluation of learning. At the kindergarten level, indicators of learning mathematics embodied in the sphere of child development has a percentage of $7.71 \%$ of the indicators on the scope of development for Kindergarten B-groups. Learning that is given is thematic learning, namely learning that has the link between one aspect of the development with other developments with a particular theme. Thus, the study of mathematics is not intact or distinguished role over each field of study

The planning of learning mathematics in kindergarten include planning the semester, the scope of development and Daily Activities Unit. Conformity planning learning math with government standards on Permendiknas No. 58/2009 belonged in the category of very fit with percentage of $94.11 \%$. Implementation of learning mathematics is the implementation of the plan has been created. Conformity between the implementation and planning of learning mathematics belongs in the category of very fit with a percentage of $95 \%$. The suitability of implementing the learning math with government standards on Permendiknas No. 58/2009 included in the category of very fit with percentage of $95.45 \%$. Suitability evaluation of learning math with government standards on Permendiknas No. 58 year 2009 included in the category of very fit with percentage of $85.71 \%$.

\section{REFERENCE}

[1] Peraturan Menteri Pendidikan Nasional Republik Indonesia No 58, "Standar Pendidikan Anak Usia Dini," pp. 1-62, 2009.

[2] W. Novitasari, "Analisis Kesultan Belajar Matematika Anak Usia 5-6 Tahun," J. Eksakta, vol. 1, pp. 19-25, 2016.

[3] Azhari, "Peningkatan Kemampuan Berpikir Kreatif Matematika Siswa Melalui Pendekatan Kontruktivisme Di Kelas VII Sekolah Menengah Pertama (SMP) Negeri 2 Banyumas III," J. Pendidik. Mat., vol. 7, pp. 2 12, 2013.

[4] R. B. Anwar, "ANALISIS KESULITAN BELAJAR MATEMATIKA PADA ANAK USIA DINI," GUIDENA, vol. 1, no. 1, 2011.

[5] M. L. T. Cossio et al., "Undang-Undang Republik Indonesia Nomor 20 Tahun 2003 Tentang Sistem Pendidikan Nasional," Uma ética para quantos?, vol. XXXIII, no. 2, pp. 81-87, 2012.

[6] A. Fitria, Mengenalkan dan Membelajarkan Matematika Pada Anak Usia Dini, J. Stud. Gend. dan Anak, vol. 1, no. 2, pp. 45-55, 2013.

[7] F. R. Sri Indah Pujiastuti, Iva Sarifah, "Pengembangan Kemampuan Matematika Anak usia 5-6 Tahun Melalui Kegiatan Sentra Seni," J. Pendidik. Anak, vol. 1, no. 2, 2012. 